\title{
Effect of Heat Treatment Conditions on the Mechanical Properties and Machinability of Ti15Sn $x$ Cu Alloys
}

\author{
Lung-Chuan Tsao ${ }^{a *}$ (1) \\ ${ }^{a}$ National Pingtung University of Science \& Technology, Institute of Materials Engineering, \\ Neipu Township, Pingtung County, Taiwan
}

Received: October 17, 2019; Revised: April 09, 2020; Accepted: May 23, 2020

In the current work, the microstructure, mechanical properties and machinability of Ti15Sn $x \mathrm{Cu}$ alloys ( $x=0$ to $2 \mathrm{wt}$. \%) were investigated. The alloy was prepared by the vacuum arc remelting and casting route and then thermally processed by solutionizing at $1000^{\circ} \mathrm{C}$ for 2 hours, followed by water quenching. By controlling the heat-treated condition and $\mathrm{Cu}$ content, the highest bending strength and modulus were obtained from three-point bending testing. The increases were mainly caused by the strengthening effects of the formation of crystallites with fine grain size and nano- $\mathrm{Ti}_{2} \mathrm{Cu}$ precipitate phase. In addition, nano- $\mathrm{Ti}_{2} \mathrm{Cu}$ precipitation was caused by crack initiation and propagation, which reduced the ductility and improved the machinability of Ti15 $\mathrm{Sn} 2 \mathrm{Cu}$ alloy.

Keywords: Ti-Sn-Cu alloy, Bending testing, Machinability, Nano-Ti, $\mathrm{Cu}$.

\section{Introduction}

In dentistry, alloys of $\mathrm{Ni}-\mathrm{Cr}, \mathrm{Co}-\mathrm{Cr}, \mathrm{Ag}, \mathrm{Au}$ are commonly used to manufacture crowns, bridges, castings, inlays and denture bases. Recently, titanium and titanium alloys have also been used for these applications $s^{1,2}$. Due to their low density, excellent biocompatibility, corrosion resistance and mechanical properties, pure Ti and its alloys are widely used for many biomedical applications today ${ }^{1-3}$. But some mechanical properties of pure Ti make it inappropriate for certain industrial or biomedical techniques, so it is necessary to enhance these mechanical properties through alloying $\mathrm{g}^{4,5}$. Another, $\alpha+\beta$ type T64 (Ti6A14V) is the most widely used because of its better physical and mechanical properties versus commercially pure titanium $(\mathrm{CP}-\mathrm{Ti})^{6}$. However, the release of $\mathrm{Al}$ and $\mathrm{V}$ ions from the alloy might cause cause serious problems ${ }^{7,8}$. Therefore, many efforts have been working out to develop non-toxic elements $\mathrm{Ti}$ alloys, such as $\mathrm{Ti}-\mathrm{Cu}^{9,10}$, Ti-Sn ${ }^{11}, \mathrm{Ti}-\mathrm{Cu}-\mathrm{Sn}^{12,13}, \mathrm{Ti}^{-\mathrm{Nb}^{14,15}}$ and Ti-15Zr-Mo alloys ${ }^{16}$. It is well known that alloying elements alter the transformation temperatures, phases/crystal structure of titanium alloys ${ }^{4,5,17}$.

Copper $(\mathrm{Cu})$ is a $\beta$ stabilizer element. The fusion temperature of the alloy decreases with increases in the amount of copper, which greatly favors casting procedures ${ }^{18}$. The Ti-Cu phase diagram indicates the formation of $\alpha$-Ti and precipitation of $\mathrm{Ti}_{2} \mathrm{Cu}$ intermetallic at a copper concentration of $7.0 \mathrm{wt} . \%{ }^{19}$. Many authors have focused on the use of $\mathrm{Ti}-\mathrm{Cu}$ alloys for industrial applications. Kikuchi et al. ${ }^{18,20}$ reports that $\mathrm{Ti}_{2} \mathrm{Cu}$ intermetallics increase the tensile strength and decrease the ductility of Ti-Cu alloys as compared with CP-Ti. Sun et al. ${ }^{21}$ showed that Ti2.5Cu alloy was strengthened by the formation of $\mathrm{Ti}_{2} \mathrm{Cu}$ intermetallic particles after the decomposition of $\beta$ phase into $\alpha$-Ti phase and $\mathrm{Ti}_{2} \mathrm{Cu}$. Yao et al. ${ }^{22}$ reported that acicular $\mathrm{Ti}_{2} \mathrm{Cu}$ particles made greater strengthening contributions than spherical ones for Ti2.5Cu alloy.

*e-mail: tlclung@mail.npust.edu.tw
Recently, the author confirm that the addition of $2 \mathrm{wt} \% \mathrm{Cu}$, the microstructure of Ti15 $\mathrm{Sn} x \mathrm{Cu}$ alloy displayed a nano-(Ti, Sn $)_{2} \mathrm{Cu}$ phase precipitated in $\alpha^{\prime}-\mathrm{Ti}(\mathrm{Sn}, \mathrm{Cu})$ with $\mathrm{TEM}^{23}$. Another, the $2.5 \mathrm{wt} \% \mathrm{Cu}$ addition to Ti6 $\mathrm{Al} x \mathrm{~V}(x=1.5$ and 4$)$ has been already commercially used to nano- $\mathrm{Ti}_{2} \mathrm{Cu}$ precipitates ${ }^{24}$. Another, Liu et al. ${ }^{25}$ reported that the antibacterial rates of the Ti-Cu alloy against $\mathrm{E}$. coli and S. aureus after $7 \mathrm{~h}$ of incubation are $99.01 \%$ and $91.66 \%$, respectively, indicating that the copper ions release from the $\mathrm{Ti}-\mathrm{Cu}$ alloy and contribute to the strong antibacterial property, but the $\mathrm{Cu}$ ion did not lead to cell cytotoxicity.

Tin ( $\mathrm{Sn}$ ) is widely used in biomedical Ti alloys. Niinomi M. has shown binary Ti-Sn alloy has been found nontoxic and nonallergic ${ }^{26}$. Therefore, $\mathrm{Sn}$ as major alloying element that is safe to use with Ti alloy. In addition, Sn, a neutral element, has little influence on the transformation temperature. $\mathrm{Sn}$ can react with $\mathrm{Ti}$ and $\mathrm{Cu}$ in the liquid state, leading to a high nucleation rate and limited grain growth upon solidification ${ }^{26}$. This limited grain size significantly increases the alloy strength ${ }^{27}$. Tsao et al. ${ }^{12}$ established that the addition of Sn to Ti7CuXSn (X = 0 - 5 wt. \%) alloys can effectively increase the solubility of $\mathrm{Cu}$ in the eutectoid microstructure $\left(\alpha-\mathrm{Ti}+\mathrm{Ti}_{2} \mathrm{Cu}\right)$, induce the transformation of an ultrafine $\alpha^{\prime}$ martensite microstructure and increase the volume fraction of the $\mathrm{Ti}_{2} \mathrm{Cu}$ phase. Han et al..$^{28}$ found that increasing the $\mathrm{Sn}$ content (1-3 at. \%) in Ti alloys can decrease the lamellar spacing in the eutectic matrix to improve the plasticity and strength. Hsu et al. ${ }^{11}$ reported that alloy hardness is directly proportional to Sn content in Ti-Sn alloy. Ho et al. ${ }^{29}$ showed that $\mathrm{Sn}$ content was significantly related to the machinability of the TixSn ( $x=1$ to 30 wt. \%) alloys. When the Sn content was $20 \mathrm{wt} . \%$ or greater, the alloys showed a combination of brittleness and some ductility properties. He et al. ${ }^{30,31}$ found that higher Sn content would shift the alloy composition from hypoeutectic to hypereutectic in the Ti-Sn phase diagram, 
and that only the compositions of Ti-Sn alloy located at the hypoeutectic region could promote the formation of a dendrite/ultrafine structure with high strength and distinct plasticity. The Ti-Sn-Cu alloy have a potential application as a dental implant material.

Therefore, the aim of this study was to evaluate the microstructure and mechanical properties of $\mathrm{Ti} 15 \mathrm{Sn} x \mathrm{Cu}(x=0$ and 2 wt. $\% \mathrm{Cu}$ ) alloy samples obtained by as-casting and heat treatment.

\section{Experimental Procedure}

\subsection{Specimen preparation and microstructure}

Ti15Sn $x \mathrm{Cu}$ samples with $x=0$ and 2 wt. \% were prepared from commercially pure Ti (grade 2), Sn (> 99.99 wt. \%) and $\mathrm{Cu}(>99.99$ wt. \%) metals using vacuum arc melting furnace. An arc melting process with a tungsten electrode on a water-cooled copper hearth was used to melt the samples. These samples were prepared in high purity argon atmosphere (>99.999\% pure). The Ti15Sn $x \mathrm{Cu}$ samples were repeatedly melted a total of five times at $1600-1630{ }^{\circ} \mathrm{C}$ for $2-3 \mathrm{~min}$ and directly cast in a copper mold. The obtained ingots were solution-treated at $1000^{\circ} \mathrm{C}$ in argon atmosphere for 2 hours and then quenched in water to room temperature.

All samples were ground with silicon carbide papers up to 2000 mesh, polished, and etched (Keller's etchant, $1 \mathrm{~mL}$ of HF, $2.5 \mathrm{~mL}$ of $\mathrm{HNO}_{3}, 1.5 \mathrm{~mL}$ of $\mathrm{HCl}$ and $95 \mathrm{~mL}$ of $\mathrm{H}_{2} \mathrm{O}$ ) to reveal the microstructure. The morphologies were studied using optical microscopy (OM) and scanning electron microscopy (SEM, S-3000H, Hitachi Co.) with a voltage of $20 \mathrm{keV}$. Energy dispersive spectroscopy (EDS) was used to analyze the composition.

\subsection{Mechanical property}

Three-point bending tests were conducted on a material testing system at a ramp rate of $1 \mathrm{~mm} / \mathrm{min}$. According to ASTM E855, the maximum bending strengths were determined with the following equation ${ }^{32}$ :

$$
\sigma=3 \frac{P L}{2 b h^{2}}
$$

Where $\sigma$ is the bending strength (MPa), P is the load $(\mathrm{N})$, $\mathrm{L}$ is the span length ( $\mathrm{mm}), \mathrm{b}$ is the specimen width ( $\mathrm{mm})$, and $\mathrm{h}$ is the specimen thickness $(\mathrm{mm})$. The mechanical properties were evaluated with a three-point bending test $t^{32,33}$. The samples were cut from the central part of the ingots to dimensions of $2.0(b) \mathrm{mm} \times 2.0(h) \mathrm{mm} \times 20.0(l) \mathrm{mm}$. All samples were polished with 1200 -grit $\mathrm{SiC}$ paper and cleaned. The modulus of elasticity in bending was calculated from the load increment and the corresponding deflection increment between two points as far apart as possible on a straight line using the equation ${ }^{32,33}$ :

$E=\frac{L^{3} \Delta P}{4 b h^{3} \Delta \delta}$

Where $\mathrm{E}$ is the modulus of elasticity in bending $(\mathrm{Pa})$, $\Delta \mathrm{P}$ is the load $\mathrm{i}(\mathrm{N})$, and $\Delta \delta$ is the the deflection at midspan. The average bending strength and modulus of elasticity in bending were taken from 5 tests under each condition.

\subsection{Machinability}

Machinability was evaluated by the cutting length. The end mill traveled for $30 \mathrm{secs}$ from one edge of the sample at a cutting depth of $0.1 \mathrm{~mm}$. The cutting feed speed of the end mill was $12 \mathrm{~mm} / \mathrm{min}$ and the cutting speed was $30 \mathrm{~m} / \mathrm{min}$. The end milling process are carried out on a CNC vertical milling centre using a TiAlN coated carbide end mill (Kennametal HER 060NN4-E) of diameter $6 \mathrm{~mm}$. No water-soluble cutting fluid was used. Five samples were used to evaluate the machinability, and the test was performed twice for each kind of sample at each cutting condition. After testing, the milling surfaces and metal chips were investigated by SEM and the average chip metal length for each kind of sample was calculated.

\section{Results and Discussion}

\subsection{Microstructural characterization}

The microstructures of the Ti15Sn $x \mathrm{Cu}$ alloys in the different treatment conditions are shown in Figures 1 and 2. Figure 1a shows that the OM image of AS Ti15Sn alloy had the typical Widmanstätten, basket-weave structure of supersaturated Ti solid solution ( $\left.\alpha^{\prime}-\mathrm{Ti}\right)$, acicular $\alpha$-Ti, and the pre-existing $\beta$-Ti grains. Hsu et al. ${ }^{11}$ reported that the Ti5Sn alloy is comprised mainly of $\alpha$ '-Ti phase ${ }^{34}$. Others have reported that $\alpha$ '-Ti plates nucleate and grow from the prior $\beta$-grain boundaries at high cooling rates ${ }^{12,35}$. The data reported here are is good agreement with the results from the previous studies ${ }^{23}$. The SEM image of AS Ti15Sn alloy shown in Figure 2a displays the same structure by OM. It is found that the lamellae structure of heat-treated (HT) Ti15Sn alloy was coarser than that of AS Ti15Sn alloy, as shown in Figures $1 \mathrm{~b}$ and 2b. From OM (Figures 1c, 1d) and SEM (Figures 2c, 2d), we can see that the 2 wt. \% Cu content slightly influenced the microstructure of the alloys. In comparison to Ti15Sn alloy, the lamellar structure of AS Ti15Sn2Cu alloy (Figure 2c) was smaller than that of AS Ti15Sn alloy (Figure 2a). Likewise, the lamellar structure of HT Ti15Sn2Cu alloy (Figure 2d) was smaller than that of HT Ti15Sn alloy (Figure 2b).

The inserted high magnification SEM microstructure shows there is a small amount of nano-particles distributed on the matrix. The EDS results indicated that mainly consisted of Ti and Sn elements with an atom ratio of Ti to Sn of about 3, corresponding to nano- $\mathrm{Ti}_{3} \mathrm{Sn}$ phase in the XRD pattern in Figure $3^{23,36}$. It can be seen that the AS Ti15Sn alloy consisted of supersaturated Ti solid solution ( $\left.\alpha^{\prime}-\mathrm{Ti}\right)$, acicular $\alpha$-Ti and nano- $\mathrm{Ti}_{3} \mathrm{Sn}$. After heat treatment, Figure $2 \mathrm{~b}$, nano- $\mathrm{Ti}_{3} \mathrm{Sn}$ phase was observed on the matrix. The XRD pattern of the HT Ti15Sn alloy exhibited $\alpha^{\prime} / \alpha$-Ti and Ti ${ }_{3}$ Sn peaks. According to the Ti-Sn phase diagram ${ }^{37}$, the $\alpha+\mathrm{Ti}_{3} \mathrm{Sn}$ formed from the supersaturated $\alpha$ '-Ti phase due to the decline of Sn solubility in $\alpha$-Ti phase as the temperature decreased from $881{ }^{\circ} \mathrm{C}$ to room temperature; i.e.,

$\alpha^{\prime}-\mathrm{Ti} \rightarrow \alpha+\mathrm{Ti}_{3} \mathrm{Sn}$

As indicated in an early report of Bulanova et al. ${ }^{38}$, the $\mathrm{Ti}_{3} \mathrm{Sn}$ phase precipitated from the primary $\beta$-Ti phase in the Ti15Sn5Si alloy on cooling. Park et al. ${ }^{39}$ reported that the 

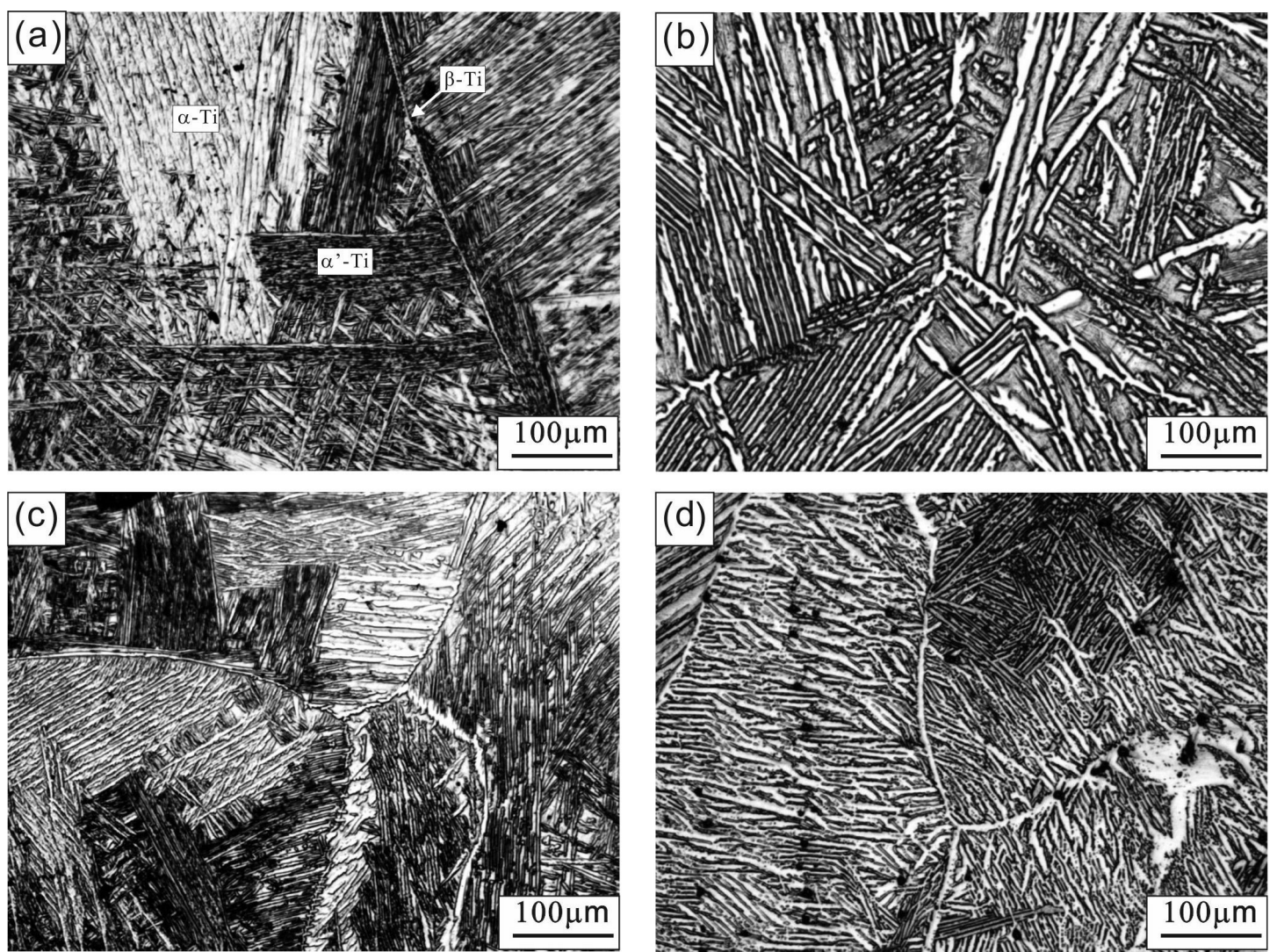

Figure 1. Optical micrographs of the Ti15SnxCu alloys: (a) AS Ti15Sn, (b) HT Ti15Sn, (c) AS Ti15Sn2Cu and (d) HT Ti15Sn2Cu.
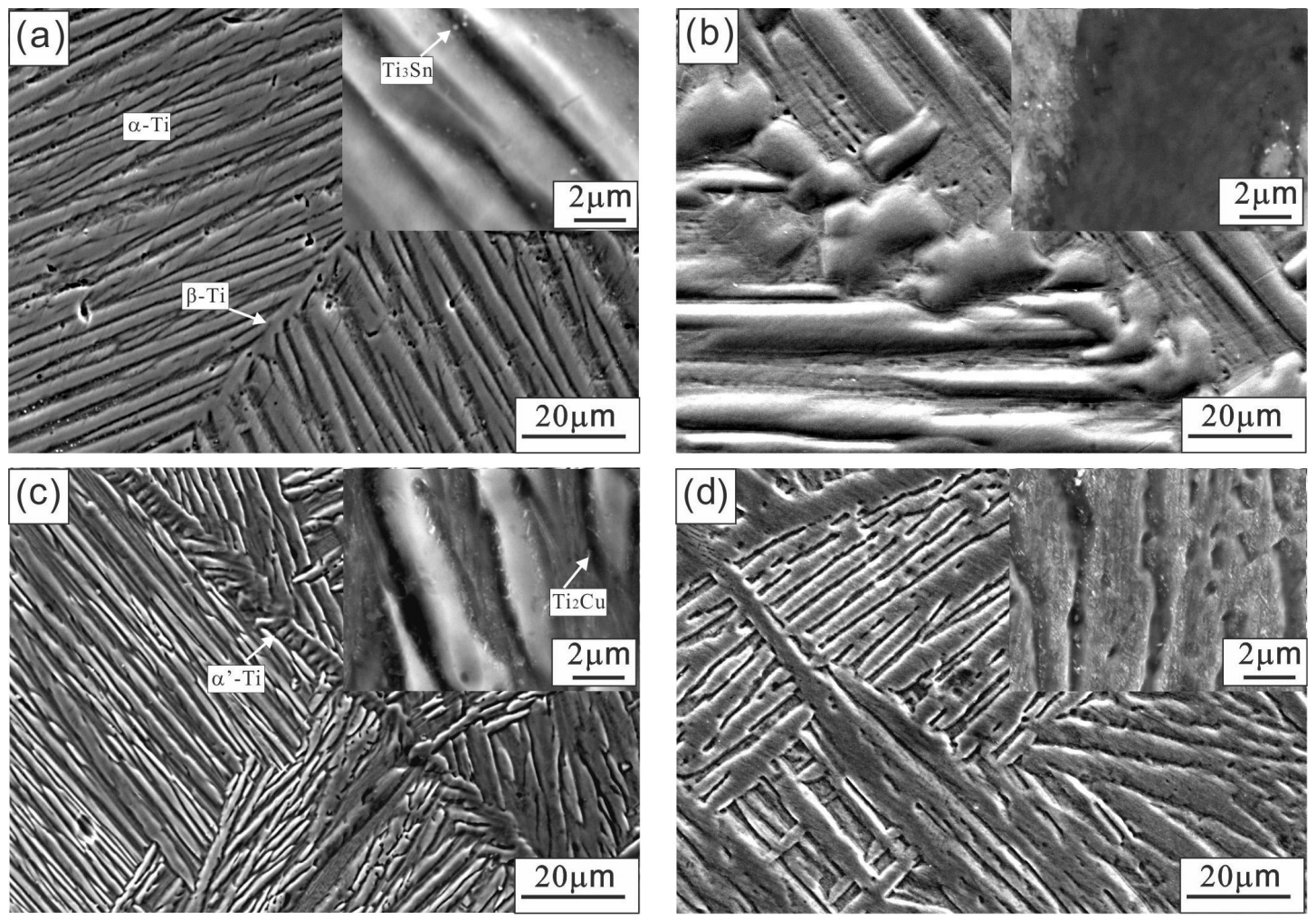

Figure 2. SEM micrograph of Ti15SnxCu alloys: (a) AS Ti15Sn, (b) HT Ti15Sn, (c) AS Ti15Sn2Cu and (d) HT Ti15Sn2Cu. The inserts show the high magnification microstructure. 
$\mathrm{Ti}_{82} \mathrm{Sn}_{18}$ eutectic alloys present a mixture of the hexagonal $\alpha$-Ti (P63/mmc) solid solution phase and the hexagonal $\mathrm{Ti}_{3} \mathrm{Sn}(\mathrm{P} 63 / \mathrm{mmc})$ intermetallic compounds (IMCs) ${ }^{39,40}$. Therefore, it is comfirmed that the nano- $\mathrm{Ti}_{3} \mathrm{Sn}$ phases were precipitated on the lath site ${ }^{23}$.

The inserted high magnification SEM image of Ti15Sn2Cu alloy shown in Figures 2c, 2d displays many particles distributed on the matrix. The XRD pattern of the AS Ti15Sn2Cu alloy exhibited some diffraction peaks, which

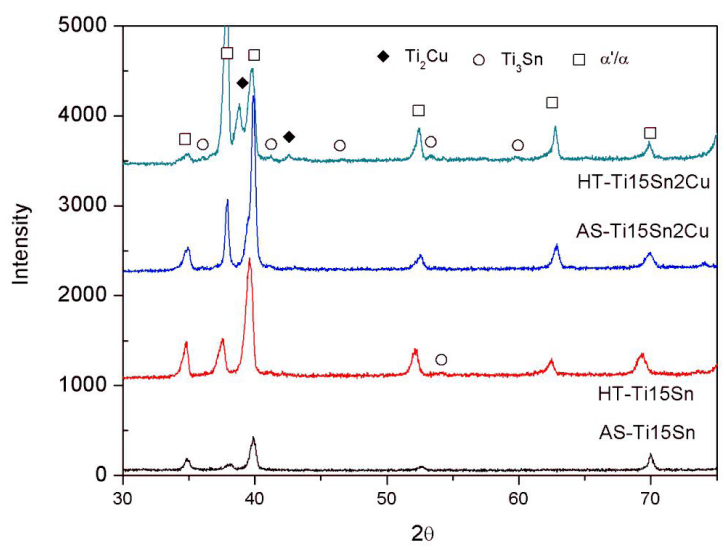

Figure 3. XRD patterns of the Ti15SnxCu alloys ${ }^{23,36}$.

Table 1. Bending property of Ti15SnxCu under different treatment condition.

\begin{tabular}{|c|c|c|c|c|}
\hline Alloy & $\begin{array}{c}\text { Alloying } \\
\text { element } \\
\left(\mathrm{wt}^{0} \%\right)\end{array}$ & $\begin{array}{c}\text { Bending } \\
\text { strength } \\
(\mathrm{MPa})\end{array}$ & $\begin{array}{c}\text { Bending } \\
\text { modulus } \\
(\mathrm{GPa})\end{array}$ & Ref. \\
\hline CP-Ti & - & $843.2 \pm 42.2$ & $98.1 \pm 5.3$ & \\
\hline ATi15Sn & - & $1275.3 \pm 63.2$ & $102.9 \pm 6.5$ & \\
\hline HT Ti15Sn & - & $1312.7 \pm 65.4$ & $110.1 \pm 5.9$ & \\
\hline AS Ti15Sn $x \mathrm{Cu}$ & $2 \mathrm{Cu}$ & $1392.2 \pm 69.5$ & $106.4 \pm 7.6$ & \\
\hline HT Ti15Sn $x \mathrm{Cu}$ & $2 \mathrm{Cu}$ & $1420.3 \pm 71.1$ & $116.4 \pm 6.8$ & \\
\hline $\mathrm{Ti5Sn} x \mathrm{Cr}$ & $0 \sim 13 \mathrm{Cr}$ & $1657-2505$ & $97-153$ & 34 \\
\hline Ti6Al7Nb & - & $1943 \pm 26$ & $111 \pm 3$ & 45 \\
\hline Ti15Mo1Bi & - & $1975 \pm 38$ & $90 \pm 1$ & \\
\hline $\mathrm{Tix} \mathrm{Si}$ & $1 \sim 12.5 \mathrm{Si}$ & $1621-2231$ & $120-180$ & 46 \\
\hline TixMo & $7.5 \sim 20 \mathrm{Mo}$ & $1395-1650$ & $55-87$ & 47 \\
\hline
\end{tabular}

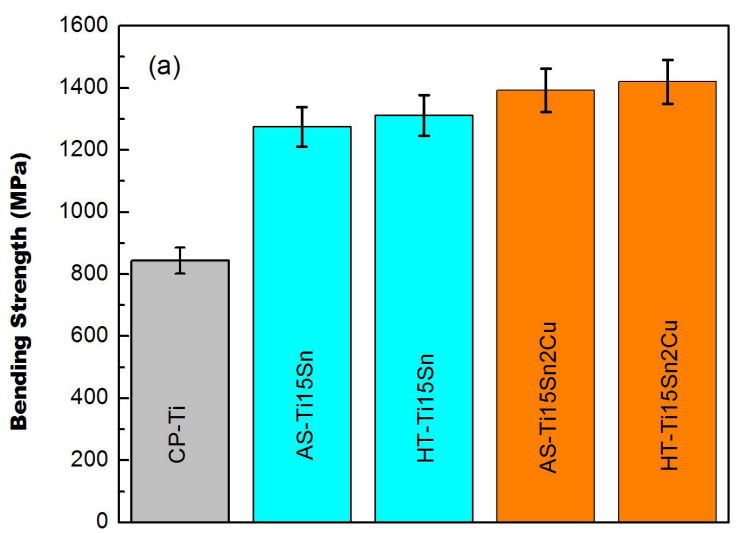

indicated $\alpha^{\prime} / \alpha$-Ti and $\mathrm{Ti}_{2} \mathrm{Cu}$ phases. After heat treatment, the Ti15Sn2Cu alloy exhibited $\alpha / \alpha$-Ti and nano- $\mathrm{Ti}_{2} \mathrm{Cu}$ phases (Figure 2d). According to the Ti-Cu phase diagram ${ }^{19}$ and many reports ${ }^{10,41-43}$, the final equilibrium microstructure of the Ti-Cu alloy with lower $\mathrm{Cu}$ content consists of $\alpha-\mathrm{Ti}$ and $\mathrm{Ti}_{2} \mathrm{Cu}$, which is formed by a eutectoid reaction. The body centered-tetragonal (bct) $\mathrm{Ti}_{2} \mathrm{Cu}$ phase ( $\mathrm{MoSi}_{2}$ type, $\mathrm{a}=0.2943 \mathrm{~nm}$ and $\mathrm{c}=1.0786 \mathrm{~nm}$ ) should be present in almost all the $\mathrm{Cu}$-bearing titanium alloys ${ }^{44}$. Yao et al. ${ }^{22}$ reported that the spherical $\mathrm{Ti}_{2} \mathrm{Cu}$ precipitates were observed to nucleate at grain boundaries and intra-grains. Therefore, the strengthening mechanisms can be attributed to the dislocations around the $\mathrm{Ti}_{2} \mathrm{Cu}$ particles. This mechanism could explain how the $\mathrm{Ti}_{2}^{2} \mathrm{Cu}$ intermetallic restricts the grain growth in the Ti15Sn2Cu alloy, leading to the smaller grain size of Ti15Sn2Cu alloy than of Ti15Sn alloy. It was expected that $\mathrm{Ti} 15 \mathrm{Sn} 2 \mathrm{Cu}$ alloy would have better mechanical behavior than Ti15Sn alloy.

\subsection{Bending strength}

The bending strengths and bending moduli of the Ti15Sn $x \mathrm{Cu}$ samples are shown in Table 1. All the Ti15Sn $x \mathrm{Cu}$ alloys had significantly higher bending strengths $(1275.3 \pm 63.2-1420.3 \pm 71.1 \mathrm{MPa})$ than the CP-Ti $(843.2 \pm 42.2 \mathrm{MPa})$. It is obvious that the bending strength of Ti15 $\mathrm{Sn} x \mathrm{Cu}$ was about 1.5 times that of CP-Ti. Numerous studies have shown that the bending strength of new Ti alloys is about $1395-2505 \mathrm{MPa}$; i.e., 1657-2505 MPa for Ti5Sn $x \mathrm{Cr}(x=0-13 \text { wt. } \%)^{34}, 1943 \pm 26 \mathrm{MPa}$ for Ti6Al7Nb, $1975 \pm 38 \mathrm{MPa}$ for Ti15Mo1Bi ${ }^{45}, 1621-2231 \mathrm{MPa}$ for TixSi $(x=1-12.5 \text { wt. } \%)^{46}$, and 1395-1650 MPa for TixMo $(x=0-13 \text { wt. } \%)^{47}$. The bending strengths of the Ti15Sn $x \mathrm{Cu}$ alloys were similar to that of TixMo Alloy.

The bending strength resulting from the AS condition was slightly lower than that resulting from the HT condition: $1275.3 \pm 63.2 \mathrm{MPa}$ vs. $1312.7 \pm 65.4 \mathrm{MPa}$ for Ti15Sn, and $1392.2 \pm 69.5 \mathrm{MPa}$ vs. $1420.3 \pm 71.1 \mathrm{MPa}$ for Ti15Sn2Cu (Table 1 and Figure 4a), respectively. Comparing the different conditions (AS vs. HT), the relative bending strengths of both Ti15Sn and Ti15Sn2Cu sample were respectively $2.9 \%$ and $2.0 \%$ higher under the HT condition than under the AS condition (Table 2 and Figure 5). Comparing OM, SEM and XRD revealed that the bending strength of the

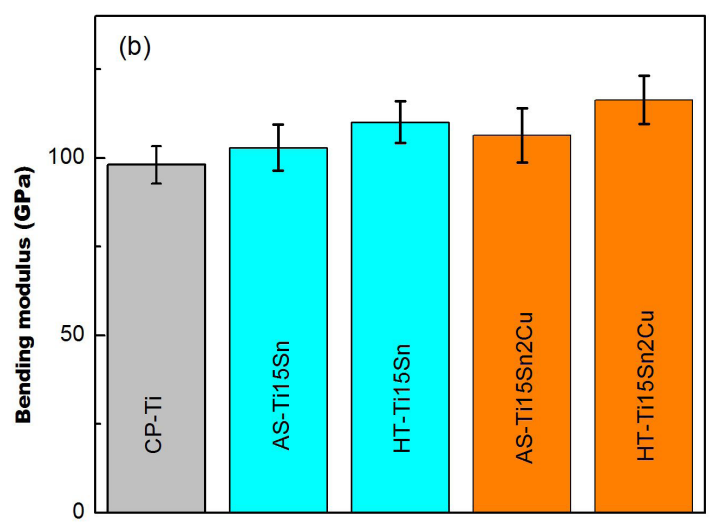

Figure 4. Bending property of Ti15SnxCu under different treatment condition: (a) bending strength and (b) bending modulus. 
HT sample increased, obviously due to the formation of the coarser $\alpha / \alpha$-Ti phase. In $\operatorname{Ref}^{48}$, the bending strength is proof of actual $\alpha$-Ti phase precipitation. Also, it can be seen from Table 3 and Figure 5 that the bending strength values of both AS and HT Ti15 $\mathrm{Sn} 2 \mathrm{Cu}$ samples were higher than that of both AS and HT Ti15Sn sample (about $9.2 \%$ and $8.2 \%$, respectively). The addition of $2 \mathrm{wt} . \% \mathrm{Cu}$ caused a large number of nano- $\mathrm{Ti}_{2} \mathrm{Cu}$ particles to precipitate in the martensite structure, and the nano- $\mathrm{Ti}_{2} \mathrm{Cu}$ particles enhanced the bending strength of the Ti15Sn2 $\mathrm{Cu}$ alloy by increasing the resistance to obstacle dislocation movement. In prevent work, both $\mathrm{Ti}_{2} \mathrm{Cu}$ and $\mathrm{Ti}_{3} \mathrm{Sn}$ nanoparticles was confirmed by transmission electron microscopy (TEM) ${ }^{12}$. From the Ti-Cu phase diagram, it is clear that the nano- $\mathrm{Ti}_{2} \mathrm{Cu}$ particles precipitated in the eutectoid reaction (at $790{ }^{\circ} \mathrm{C}$ ) from $\beta$ phase ${ }^{19,22}$,

$$
\beta \rightarrow \alpha+\mathrm{Ti}_{2} \mathrm{Cu}
$$

The $\mathrm{Ti}_{2} \mathrm{Cu}$ particles mainly precipitated from the supersaturated $\alpha$ '-Ti phase due to the decline of $\mathrm{Cu}$ solubility in $\alpha$-Ti phase as the temperature decreased from $790{ }^{\circ} \mathrm{C}$ to room temperature; i.e.,

$$
\alpha^{\prime} \rightarrow \alpha+\mathrm{Ti}_{2} \mathrm{Cu}
$$

The XRD results in Figure 3 indicate that the intensity of the $\mathrm{Ti}_{2} \mathrm{Cu}$ peak $(2 \theta=38.33)$ increased after heat treatment, leading to a high volume fraction of $\mathrm{Ti}_{2} \mathrm{Cu}$. Thus, the bending strength of the HT Ti15Sn2Cu alloy was higher than those of the as-cast ones. Kikuchi et al. ${ }^{18}$ noted that $\mathrm{Ti}_{2} \mathrm{Cu}$ precipitates can strengthen Ti alloy. Sun et al. ${ }^{21}$ reported that nano- $\mathrm{Ti}_{2} \mathrm{Cu}$ precipitates hinder the dislocation movement and thereby increase the mechanical property. A number of articles have shown that Sn can strengthen Ti alloys due to the solid-solution strengthening effect and the formation of $\mathrm{Ti}_{3} \mathrm{Sn}$ in the alloy ${ }^{29,30}$.

Table 2. The relative ratios (\%) of bending strength and bending modulus of AS versus HT of Ti15Sn $x \mathrm{Cu}$.

\begin{tabular}{ccc}
\hline Alloy & Bending strength & Bending modulus \\
\hline Ti15Sn & +2.9 & +7.0 \\
\hline Ti15Sn2Cu & +2.0 & +9.4 \\
\hline
\end{tabular}

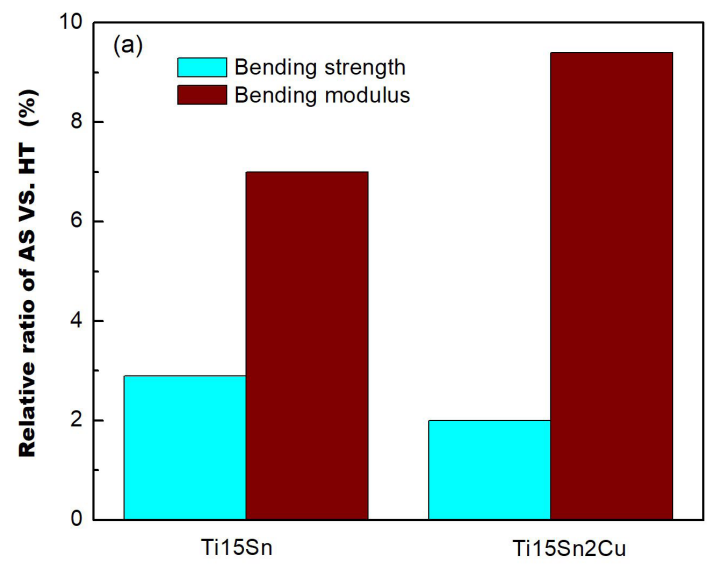

The Bending modulus results are shown in Table 1 and Figure $4 \mathrm{~b}$. The bending moduli $(102.9 \pm 6.5 \mathrm{GPa}-116.4 \pm 6.8 \mathrm{GPa})$ of all the Ti15Sn $x \mathrm{Cu}$ alloys were higher than that of CP-Ti $(98.1 \pm 5.3 \mathrm{GPa})$. The bending moduli of the Ti15SnxCu alloys were similar to those of Ti6Al7Nb $(111 \pm 3 \mathrm{GPa})^{45}$ and Ti5SnxCr alloy $(97-153 \mathrm{GPa})^{34}$. To simplify the analysis (Table 2 and Figure 5a), the relative ratios of the bending moduli were higher for the HT condition $(+7.0 \%$ for Ti1 $5 \mathrm{Sn}$ alloy and $+9.4 \%$ for $\mathrm{Ti} 15 \mathrm{Sn} 2 \mathrm{Cu}$ alloy) than for the AS condition. Relative to the Ti15Sn alloy (Table 3 and Figure $5 \mathrm{~b}$ ), the bending modulus of the Ti15 $\mathrm{Sn} 2 \mathrm{Cu}$ alloy was enhanced by $3.4 \%$ in the AS condition and by $5.7 \%$ in the HT condition. It is known that a higher elastic modulus is essential to minimize elastic deformation. In addition, Kikuchi et al. ${ }^{49,50}$ and Guillet et al. ${ }^{51}$ reported that hard IMCs generally have a higher elastic modulus than the constituting elements, and that the increase in the modulus of Ti $15 \mathrm{Sn} 2 \mathrm{Cu}$ alloy was due to the formation of the $\mathrm{Ti}_{2} \mathrm{Cu}$ phase in the $\alpha$ matrices. The elastic modulus is one of the most important properties of a dental structural alloy, such as bridges and partial denture frameworks. In general, a higher elastic modulus is also beneficial for machining titanium alloys. Therefore, the HT Ti15Sn2Cu alloys possessed better bending strengths and moduli mainly due to the strengthening effects of the crystallites with fine grain sizes and nano- $\mathrm{Ti}_{2} \mathrm{Cu}$ precipitates.

\subsection{Fracture surface}

Figures 6 and 7 show SEM micrographs of the fractured surfaces of the Ti15 $\mathrm{Sn} x \mathrm{Cu}$ specimens after three-point bending tests. Figure 6a presents two common fracture surfaces of AS Ti15Sn alloy after three-point bending tests. The surfaces were mostly interlamellar fractured (gray smooth) and a few, narrow translamellar fractured (light rough). Interlamellar ruptures were clearly visible in the fractured structures of the AS Ti15Sn alloy at the higher magnification of SEM fractographs (Figure 7a). The river pattern was clearly visible. After heat treating, the fracture surface in Figure $6 \mathrm{~b}$ appeared to be mixed interlamellar/translamellar. In the high magnification image in Figure $7 \mathrm{~b}$, the dimples can be seen clearly. Since interlamellar strength is significantly lower than translamellar strength, the strength of the HT Ti15Sn sample was higher than that of the AS Ti15Sn sample.

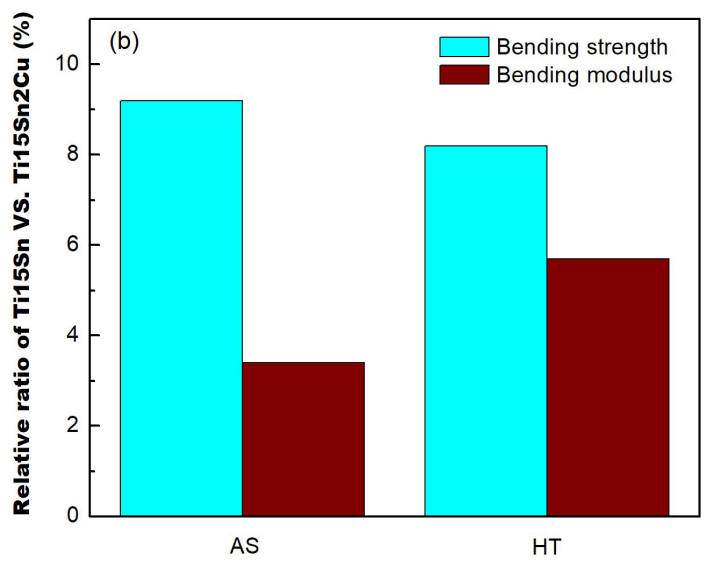

Figure 5. The relative ratios (\%) of both bending strength and bending modulus: (a) AS versus HT and (b) Ti15Sn versus Ti15Sn2Cu. 
The effect of adding $2 \mathrm{wt} \% \mathrm{Cu}$ into the Ti15Sn $x \mathrm{Cu}$ alloy is visible in the fracture images in Figure $6 \mathrm{c}$ and $6 \mathrm{~d}$. The randomly oriented colonies (with respect to the loading direction) and mostly translamellar fracture were observed. A high magnification image of the interlamellar area is given in Figure 7c, where white nanoparticles can be seen clearly. According to Energy Dispersive Spectroscopy (EDS) analysis, the chemical composition (wt. \%) of the white nano-particles was $\mathrm{Ti}(83.98 \%), \mathrm{Sn}(3.82 \%)$, and $\mathrm{Cu}(12.20 \%)$,

Table 3. The relative ratios (\%) of bending strength and bending modulus of Ti15Sn versus Ti15Sn2Cu alloy.

\begin{tabular}{ccc}
\hline Condition & Bending strength & Bending modulus \\
\hline AS & +9.2 & +3.4 \\
\hline HT & +8.2 & +5.7 \\
\hline
\end{tabular}
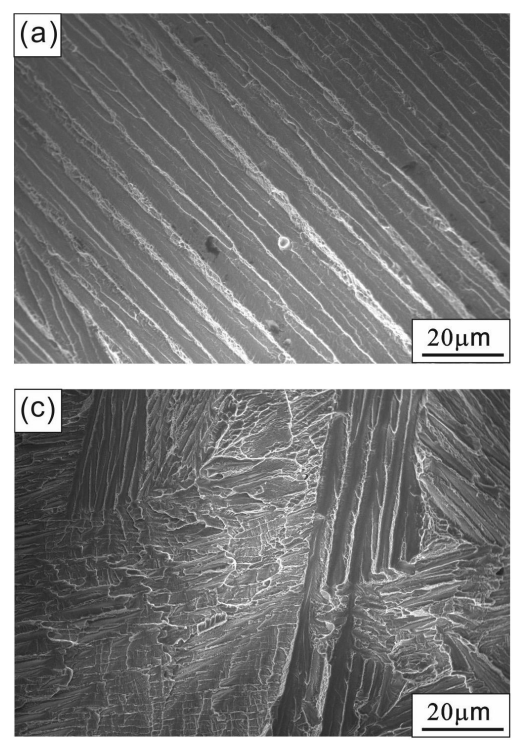

Figure 6. SEM fractographs of Ti15SnxCu alloys: (a) AS Ti15Sn, (b) HT Ti15Sn, (c) AS Ti15Sn2Cu and (d) HT Ti15Sn2Cu.
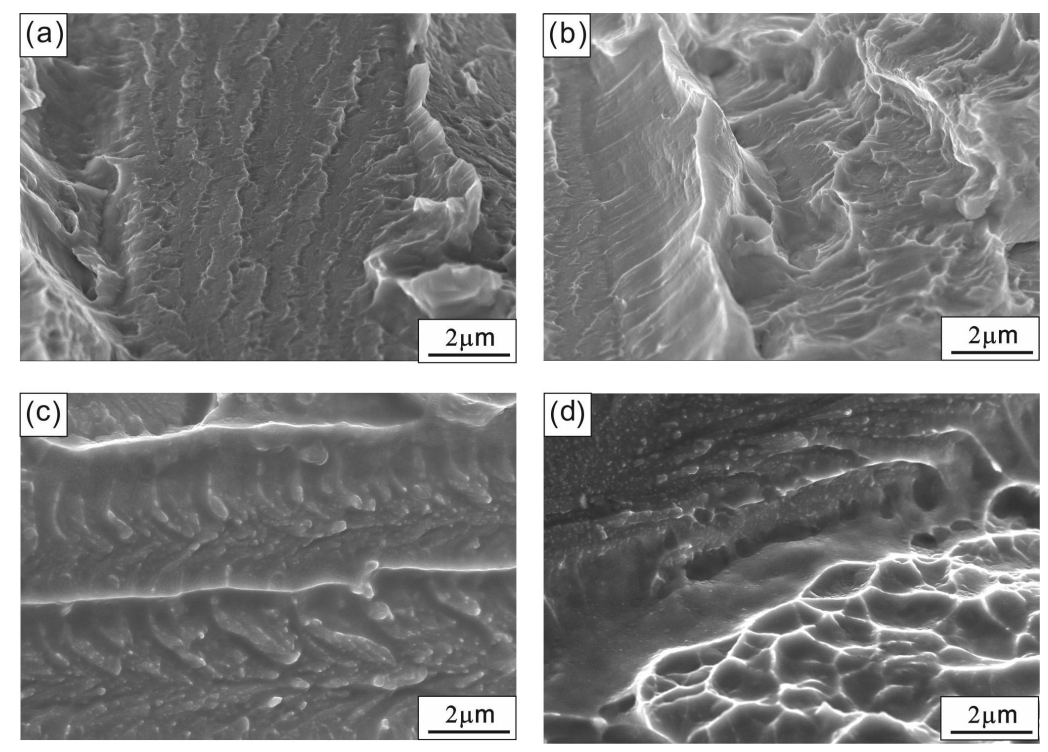

Figure 7. The higher magnification SEM fractographs of Ti15SnxCu alloys: (a) AS Ti15Sn, (b) HT Ti15Sn, (c) AS Ti15Sn2Cu and (d) HT Ti15Sn2Cu.
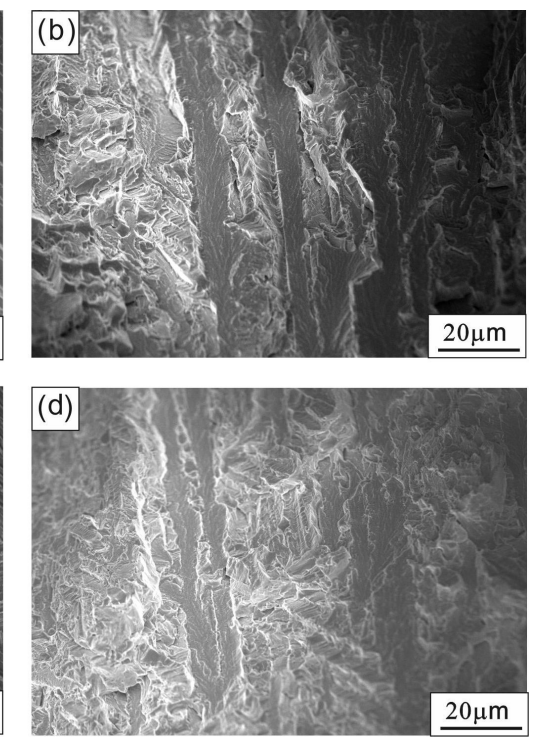

which approximates that of the nano- $\mathrm{Ti}_{2} \mathrm{Cu}$ phase. The same phenomenon was also observed in the heat treated Ti15Sn $2 \mathrm{Cu}$ sample (Figures $6 \mathrm{~d}$ and $7 \mathrm{~d}$ ), confirming that the nano- $\mathrm{Ti}_{2} \mathrm{Cu}$ particles could improve the machine property of the $115 \mathrm{Sn} 2 \mathrm{Cu}$ samples. It is clear that due to the higher bending rength of $\mathrm{Ti} 15 \mathrm{Sn} 2 \mathrm{Cu}$ alloy, the brittle nano- $\mathrm{Ti}_{2} \mathrm{Cu}$ phase precipitated, and those precipitates restricted the motion of bending initiated and propagated in the brittle nano- $\mathrm{Ti}_{2} \mathrm{Cu}$ particles in an early stage of the shearing.

\subsection{Machinability}

Figure 8 shows the cut surfaces of the Ti15Sn $x \mathrm{Cu}$ alloys. Cutting scars (mark a) are obvious on the cutting surface of the AS Ti15Sn alloy (Figure 8a), as well as small amounts 

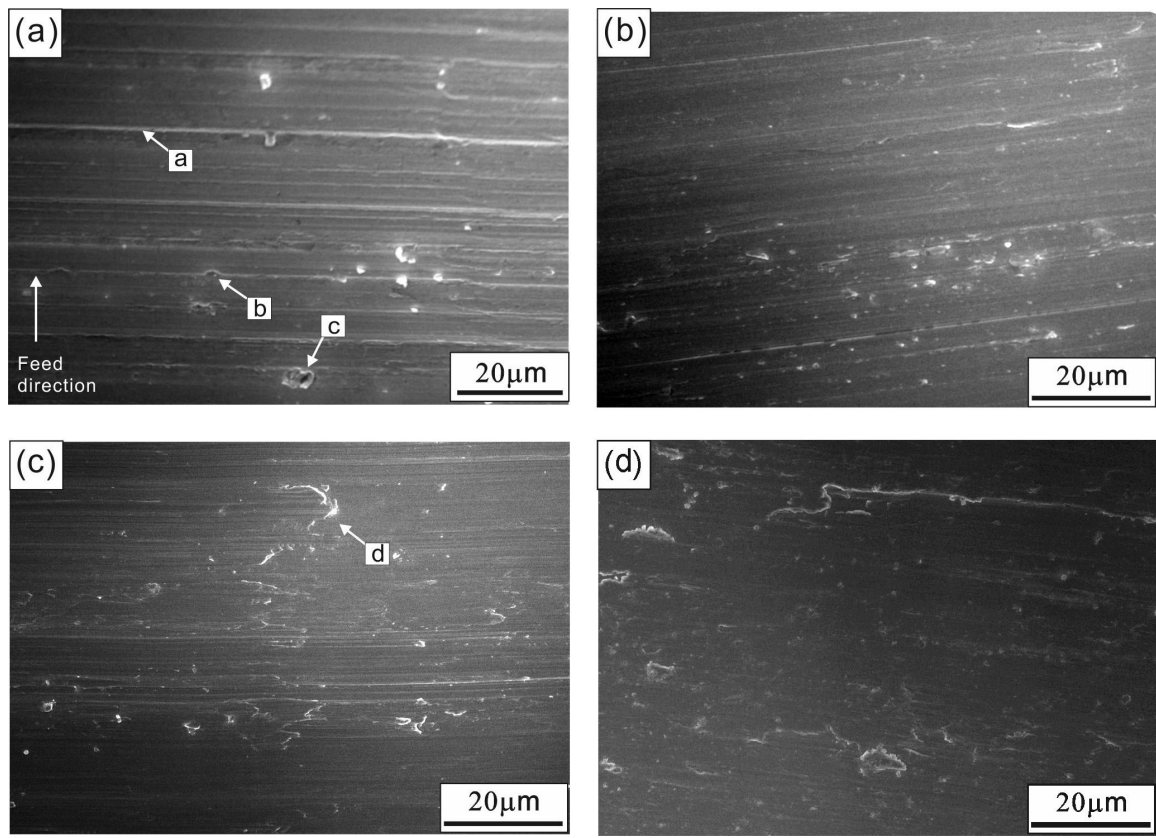

Figure 8. Cut surfaces of Ti15SnxCu samples: (a) AS Ti15Sn, (b) HT Ti15Sn, (c) AS Ti15Sn2Cu and (d) HT Ti15Sn2Cu.
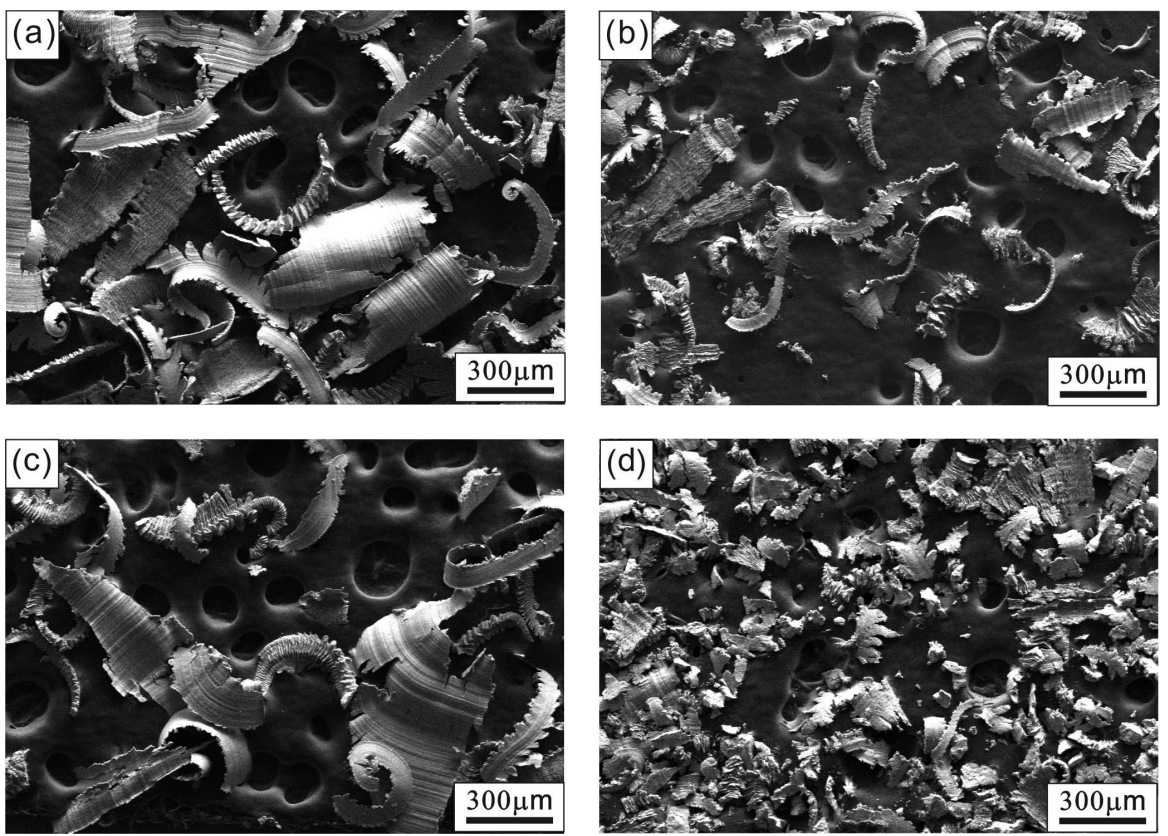

Figure 9. Metal chips cut from Ti15SnxCu samples: (a) AS Ti15Sn, (b) HT Ti15Sn, (c) AS Ti15Sn2Cu and (d) HT Ti15Sn2Cu.

of smears (mark b) and micro-voids (mark c). The cutting surface of the HT Ti15Sn2Cu alloy (Figure 8d) had fewer cutting marks than did those of the other samples. The order of cutting traces in the machinability testing was as follows: AS Ti15Sn $>$ HT Ti15Sn $>$ AS Ti15Sn2Cu $>$ HT Ti15Sn2Cu. Compared with that of Ti15Sn alloy, the cutting surface of Ti15Sn $x \mathrm{Cu}$ alloy with 2 wt. \% Cu had increased tearing (mark d). It is well known that lower ductility is generally beneficial to the machinability of metals ${ }^{52}$. It is reported that scar morphologies are related to grind adhesion, and the relative low hardness and strength of alloys cause chatter vibration or deformation of the work piece during machining ${ }^{11,53}$. Figure 9 shows SEM images of the metal chips resulting from the machinability testing of the Ti15Sn $x \mathrm{Cu}$. The metal chips of the Ti15Sn2Cu alloy were finer than those of the Ti15Sn alloy. As shown in Figure 10, the average size of the metal chips of Ti15Sn2Cu alloys is order: AS Ti15Sn $(645 \pm 56 \mu \mathrm{m})>$ HT Ti15Sn $(547 \pm 42 \mu \mathrm{m})>\operatorname{AS~Ti} 15 \mathrm{Sn} 2 \mathrm{Cu}(354 \pm 46 \mu \mathrm{m})>$ HT Ti15Sn2Cu $(286 \pm 32 \mu \mathrm{m})$. Especially, the HT Ti15Sn2Cu alloy produced much finer metal chips, which are reported to be more suitable for machinability ${ }^{20,54}$. From the above experiments, it became obvious that the nano- $\mathrm{Ti}_{2} \mathrm{Cu}$ 


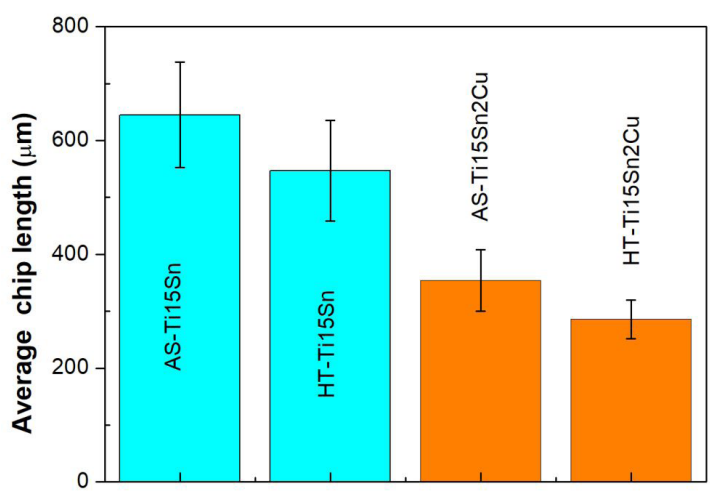

Figure 10. Average length of metal chips of Ti15SnxCu alloys.

precipitates caused a loss of ductility and facilitated more effective machinability of Ti15Sn2Cu alloy because small broken fragments more readily formed ${ }^{20}$.

\section{Conclusion}

In the current investigation, the effect of heat treatments on the microstructure, mechanical and machinability properties of Ti15 $\mathrm{Sn} x \mathrm{Cu}$ was investigated, and the following points were concluded:

1. The Ti15Sn alloy exhibits (fine $\alpha^{\prime} / \alpha-\mathrm{Ti}+$ nano- $\mathrm{Ti}_{3} \mathrm{Sn}$ ) and (coarse $\alpha^{\prime} / \alpha-\mathrm{Ti}+\mathrm{Ti}_{3} \mathrm{Sn}$ ) phases under the as-cast and HT conditions, respectively. However, Ti15Sn $x \mathrm{Cu}$ with 2 wt. \% Cu (Ti15Sn2Cu) alloy comprises $\alpha / \alpha-\mathrm{Ti}+$ nano- $\mathrm{Ti}_{2} \mathrm{Cu}$ phase under such conditions.

2. All the Ti15SnxCu alloys had higher bending strengths $(1275.3 \pm 63.2-1420.3 \pm 71.1 \mathrm{MPa})$ than that of CP-Ti $(843.2 \pm 42.2 \mathrm{MPa})$. Notably, the bending strengths of the HT alloys were higher than those of theAS alloys. The HT Ti15Sn2Cu alloy also had the highest bending strength and modulus, mainly due to the strengthening effects of the crystallites with fine grain sizes and nano- $\mathrm{Ti}_{2} \mathrm{Cu}$ precipitates.

3. In the AS T15Sn alloy, the predominantly observed fracture mode was interlamellar-fracture. In the HT Ti15Sn alloy, the fracture mode was mixed interlamellar/translamellar. However, adding 2 wt. $\% \mathrm{Cu}$ to the Ti15Sn $x \mathrm{Cu}$ alloy change the fracture structures to mostly translamellar fracture, especially in the case of the heat treated Ti15Sn2Cu alloy.

4. It was confirmed that the nano- $\mathrm{Ti}_{2} \mathrm{Cu}$ precipitation was caused by crack initiation and propagation, which reduced ductility and improved the machinability of Ti15Sn2Cu alloy.

\section{Acknowledgments}

The authors acknowledge the financial support of this work from the Ministry of Science and Technology, Taiwan, under Project No. MOST 106-2221-E-020-015, 107-222-E-020-011-MY2. SEM was performed by the Precision Instrument Center of National Pingtung University of Science and Technology, Taiwan.

\section{References}

1. Ida K, Tani Y, Tsutsumi S, Togaya T, Nambu T, Suese K, et al. Clinical application of pure titanium crown. Dent Mater J. 1985;4(2):191-5. http://dx.doi.org/10.4012/dmj.4.191. PMid:3916818.

2. Van Noort R. The implant material of today. J Mater Sci. 1987;22(11):3801-11. http://dx.doi.org/10.1007/BF01133326.

3. Lautenschlager EP, Monaghan P. Titanium and titanium alloys as dental materials. Int Dent J. 1993;43(3):245-53. PMid:8406955.

4. González JEG, Mirza-Rosca JC. Study of the corrosion behavior of titanium and some of its alloys for biomedical and dental implant applications. J Electroanal Chem. 1999;471(2):109-15. http://dx.doi.org/10.1016/S0022-0728(99)00260-0.

5. Collings EW. Introduction to titanium alloy design. In: Water JL, Jackson MR, Sims CT, editors. Alloying. Metals Park: ASM International; 1988.

6. Zwicker U, Buhler K, Muller R, Beck H, Schmid HJ, Ferstl J. Mechanical properties and tissue reactions of a titanium alloy for implant material. In: Kimura, I, editor. Titanium'80, Science and Technology; 1980; Kyoto, Japan. New York: Metallurgical Society of AIME; 1980. p. 505-514.

7. Wapner KL. Implications of metallic corrosion in total knee arthroplasty. Clin Orthop Relat Res. 1991;271:12-20. http:// dx.doi.org/10.1097/00003086-199110000-00004.

8. Agins HJ, Alcock NW, Bansal M, Salvati EA, Wilson PD Jr, Pellicci PM, et al. Metallic wear in failed titanium-alloy total hip replacements: a histological and quantitative analysis. J. Bone Joint Surg. 1988;70(3):347-56. http://dx.doi.org/10.2106/00004623198870030-00005.

9. Tsao LC. Basic electrochemical behavior of Ti-7Cu alloys for medical applications. Acta Phys Pol A. 2012;122(3):561-4. http://dx.doi.org/10.12693/APhysPolA.122.561.

10. Ohkubo C, Shimura I, Aoki T, Hanatani S, Hosoi T, Hattori $\mathrm{M}$, et al. Wear resistance of experimental Ti-Cu alloys. Biomaterials. 2003;24(20):3377-81. http://dx.doi.org/10.1016/ S0142-9612(03)00157-1. PMid:12809765.

11. Hsu HC, Lin HC, Wu SC, Hong YS, Ho WF. Microstructure and grindability of as-cast Ti-Sn alloys. J Mater Sci. 2010;45(7):18306. http://dx.doi.org/10.1007/s10853-009-4166-4.

12. Tsao LC, Wu RW, Wu MW, Huang CH, Chen RS. Formation of ultrafine structure in as cast Ti7CuXSn alloys. Mater Sci Technol. 2013;29(12):1529-36. http://dx.doi.org/10.1179/174 3284713 Y.0000000257.

13. Tsao LC. Effect of Sn addition on the corrosion behavior of Ti7Cu-Sn cast alloys for biomedical applications. Mater Sci Eng C Mater Biol Appl. 2015;46:246-52. http://dx.doi.org/10.1016/j. msec.2014.10.037. PMid:25491984.

14. Silva LM, Claro APRA, Buzalaf MAR, Grandini CR. Influence of the substitutional solute on the mechanical properties of Ti-Nb binary alloys for biomedical use. Mater. Res. Ibero Am. J. Mater. 2012;15(3):355-8. http://dx.doi.org/10.1590/ S1516-14392012005000040.

15. Lopes ESN, Cremasco A, Contieri RJ, Caram R. Effects of aging heat treatment on the microstructure of Ti-Nb and Ti-Nb-Sn alloys employed as biomaterials. Adv Mat Res. 2011;324:61-4. http://dx.doi.org/10.4028/www.scientific.net/AMR.324.61.

16. Correa DRN, Kuroda PAB, Lourenço ML, Buzalaf MAR, Mendoza ME, Archanjo BS, et al. Microstructure and selected mechanical properties of aged Ti-15Zr-based alloys for biomedical applications. Mater Sci Eng C Mater Biol Appl. 2018;91:762-71. http://dx.doi.org/10.1016/j.msec.2018.06.017. PMid:30033311.

17. He G, Hagiwara M. Ti alloy design strategy for biomedical applications. Mater Sci Eng C. 2006;26(1):14-9. http://dx.doi. org/10.1016/j.msec.2005.03.007.

18. Kikuchi M, Takada Y, Kiyosue S, Yoda M, Woldu M, Cai $\mathrm{Z}$, et al. Mechanical properties and microstructures of cast 
Ti-Cu alloys. Dent Mater. 2003;19(3):174-81. http://dx.doi. org/10.1016/S0109-5641(02)00027-1. PMid:12628428.

19. Murray JL. Binary alloy phase diagrams: Cu-Ti. In: Baker H, editor. Alloy phase diagrams. Metals Park: ASM International; 1987.

20. Kikuchi M, Takada Y, Kiyosue S, Yoda M, Woldu M, Cai Z, et al. Grindability of cast Ti-Cu alloys. Dent Mater. 2003;19(5):37581. http://dx.doi.org/10.1016/S0109-5641(02)00080-5. PMid:12742432.

21. Sun QY, Yu ZT, Zhu RH. Dynamic fracture toughness of Ti$2.5 \mathrm{Cu}$ alloy strengthened with nano-scale particles at room and low temperatures. Mater Sci Eng A. 2008;131:483-4. http:// dx.doi.org/10.1016/j.msea.2006.11.171.

22. Yao X, Sun QY, Xiao L, Sun J. Effect of $\mathrm{Ti}_{2} \mathrm{Cu}$ precipitates on mechanical behavior of Ti-2.5Cu alloy subjected to different heat treatments. J Alloys Compd. 2009;484(1-2):196-202. http://dx.doi.org/10.1016/j.jallcom.2009.04.095.

23. Tsao LC. Effects of $\mathrm{Cu}$ addition on the microstructure and mechanical properties of Ti15Sn alloys. Mater Sci Eng A. 2009;698:98-103. http://dx.doi.org/10.1016/j.msea.2017.05.046.

24. Mukhopadhyay P, Singh V, Bhattacharjee A, Gogia AK. Effect of Nano $\mathrm{Ti}_{2} \mathrm{Cu}$ precipitates in Ti6Al4V2.5Cu alloy. Mater Today. 2015;2:3580-5.

25. Liu J, Zhang X, Wang H, Li F, Li M, Yang K, et al. The antibacterial properties and biocompatibility of a Ti-Cu sintered alloy for biomedical application. Biomed Mater. 2014;9(2):025013. http:// dx.doi.org/10.1088/1748-6041/9/2/025013. PMid:24565798.

26. Niinomi M. Recent research and development in titanium alloys for biomedical applications and healthcare goods. Sci Technol Adv Mater. 2003;4(5):445-54. http://dx.doi.org/10.1016/j. stam.2003.09.002.

27. He G, Hagiwara M. Bimodal structured Ti-base alloy with large elasticity and low Young's modulus. Mater Sci Eng C. 2005;25(3):290-5. http://dx.doi.org/10.1016/j.msec.2005.03.001.

28. Han JH, Park DH, Bang CW, Yi S, Lee WH, Kim KB. Sn effect on microstructure and mechanical properties of ultrafine eutectic Ti-Fe-Sn alloys. J Alloys Compd. 2009;483(1-2):44-6. http:// dx.doi.org/10.1016/j.jallcom.2008.07.162.

29. Ho WF, Wu SC, Hong YS, Hsu HC. Evaluation of the machinability of Ti-Sn alloys. J Alloys Compd. 2010;502(1):112-7. http:// dx.doi.org/10.1016/j.jallcom.2010.03.227.

30. He G, Eckert J, LÖser W, Hagiwara M. Composition dependence of the microstructure and the mechanical properties of nano/ ultrafine-structured. Acta Mater. 2004;52:3035-46. http://dx.doi. org/10.1016/j.actamat.2004.03.006.

31. He G, Hagiwara M, Eckert J. Effect of Sn on microstructure and mechanical properties of Ti-base dendrite/ultrafine-structured multicomponent alloys. Metall Mater Trans, A Phys Metall Mater Sci. 2004;35(11):3605-12. http://dx.doi.org/10.1007/ s11661-004-0196-3.

32. ASTM: American Society for Testing and Materials. ASTM E855-90: standard test methods for bend testing of metallic flat materials for spring applications involving static loading. West Conshohocken: ASTM; 1990.

33. Hsu HC, Wu SC, Hong YS, Ho WF. Mechanical properties and deformation behavior of as-cast Ti-Sn alloys. J Alloys Compd. 2009;479(1-2):390-4. http://dx.doi.org/10.1016/j. jallcom.2008.12.064.

34. Hsu HC, Wu SC, Hsu SK, Chen CY, Ho WF. Structure and mechanical properties of as-cast Ti-5Sn-xCr alloys. Mater Sci Eng A. 2014;606:157-64. http://dx.doi.org/10.1016/j. msea.2014.03.099.

35. Souza SA, Afonso CRM, Ferrandini PL, Coelho AA, Caram R. Effect of cooling rate on Ti-Cu eutectoid alloy microstructure. Mater Sci Eng C. 2009;29(3):1023-8. http://dx.doi.org/10.1016/j. msec.2008.09.007.

36. Tsao LC, Chang SY. Influence of Cu addition on the structures and properties of Ti15 $\mathrm{Sn} x \mathrm{Cu}$ alloys. Mater Sci Technol.
2017;33(15):1846-53. http://dx.doi.org/10.1080/02670836.2 017.1325565 .

37. Murray JL. The Sn-Ti (Tin-Titanium) system. In: Murray JL, editor. Phase diagrams of binary titanium alloys. Metals Park: ASM International; 1987. p. 294-99.

38. Bulanova M, Tretyachenko L, Meleshevich K, Saltykov V, Vereshchaka V, Galadzhyj O, et al. Influence of tin on the structure and properties of as-cast Ti-rich T-Si alloys. J Alloys Compd. 2003;350(1-2):164-73. http://dx.doi.org/10.1016/ S0925-8388(02)00971-4.

39. Park EM, Lee CH, Park JM, Han JH, Song GA, Kim JT, et al. Heterogeneous duplex structured Ti-Sn-Mo alloys with high strength and large plastic deformability. J Alloys Compd. 2013;574:546-51. http://dx.doi.org/10.1016/j.jallcom.2013.05.061.

40. Park EM, Song GA, Han JH, Seo Y, Park JY, Kim KB. Solidstate phase transformation-induced heterogeneous duplex structure in Ti-Sn-Fe alloys. J Alloys Compd. 2012;515:86-9. http://dx.doi.org/10.1016/j.jallcom.2011.11.078.

41. Meng XL, Sato $\mathrm{M}$, Ishida $\mathrm{A}$. Influence of $\mathrm{Ti}_{2} \mathrm{Cu}$ precipitates on B19 martensite structure in a Ti-rich $\mathrm{Ti}-\mathrm{Ni}-\mathrm{Cu}$ thin film. Philos Mag Lett. 2008;88(8):575-82. http://dx.doi. org/10.1080/09500830802322152.

42. Hu Z, Zhan Y, She J, Zhang G, Peng D. The phase equilibria in the Ti-Cu-Y ternary system at 773K. J Alloys Compd. 2009;485(12):261-3. http://dx.doi.org/10.1016/j.jallcom.2009.06.066.

43. Ma Z, Ren L, Liu R, Yang K, Zhang Y, Liao Z, et al. Effect of heat treatment on $\mathrm{Cu}$ distribution, antibacterial performance and cytotoxicity of Ti-6Al-4V-5Cu alloy. J Mater Sci Technol. 2015;31(7):723-32. http://dx.doi.org/10.1016/j.jmst.2015.04.002.

44. Gelius U, Kolpachev AB, Kolpacheva OV, Nikiforov IY, Chularis AA. Electronic energy structure of $\mathrm{TiCu}_{\mathrm{Cnd}} \mathrm{Ti}_{2} \mathrm{Cu}$. J Struct $\mathrm{Chem}$. 2001;42(4):578-82. http://dx.doi.org/10.1023/A:1013185624613.

45. Lin CW, Ju CP, Lin JHC. Comparison among mechanical properties of investment-cast C.P. Ti, Ti-6Al-7Nb and Ti-15Mo1Bi alloys. Mater Trans. 2004;45(10):3028-32. http://dx.doi. org/10.2320/matertrans.45.3028.

46. Hsu HC, Wu SC, Hsu SK, Li YC, Ho WF. Structure and mechanical properties of as-cast Ti-Si alloys. Intermetal. 2014;47:11-6. http://dx.doi.org/10.1016/j.intermet.2013.12.004.

47. Ho WF. Effect of omega phase on mechanical properties of Ti-Mo alloys for biomedical applications. J Med Biol Eng. 2008;28:47-51.

48. Ho W-F, Cheng C-H, Pan C-H, Wu S-C, Hsu H-C. Structure, mechanical properties and grindability of dental Ti-10Zr-X alloys. Mater Sci Eng C. 2009;29(1):36-43. http://dx.doi. org/10.1016/j.msec.2008.05.004.

49. Kikuchi M, Takahashi M, Okuno O. Elastic moduli of cast Ti-Au, Ti-Ag, and Ti-Cu alloys. Dent Mater. 2006;22(7):641-6. http:// dx.doi.org/10.1016/j.dental.2005.05.015. PMid:16221490.

50. Kikuchi M, Takahashi M, Okuno O. Elastic properties of experimental titanium alloys. In: Interface Oral Health Science 2007: Proceedings of the 2nd International Symposium for Interface Oral Health Science; 2007; Sendai, Japan. Tokyo: Springer; 2007. p. 345-6.

51. Guillet L, Le Roux R. Elastic behavior. In: Westbrook JH, editor. Intermetallic compounds. New York: R.E. Krieger; 1977. p. 453-63.

52. Hsu HC, Wu SC, Hsu SK, Hsu KH, Ho WF. Machinability evaluation of Ti-5 $\mathrm{Nb}-\mathrm{xFe}$ alloys for dental applications. J Mater Eng Perform. 2015;24(3):1332-9. http://dx.doi.org/10.1007/ s11665-014-1375-z.

53. Hsu HC, Hsu SK, Wu SC, Lee CJ, Ho WF. Structure and mechanical properties of as-cast Ti-5Nb-xFe alloys. Mater Charact. 2010;61(9):851-8. http://dx.doi.org/10.1016/j. matchar.2010.05.003.

54. Takahashi M, Kikuchi M, Okuno O. Mechanical properties and grindability of experimental Ti-Au alloys. Dent Mater J. 2004;23(2):203-10. http://dx.doi.org/10.4012/dmj.23.203. PMid:15287569. 